\title{
COMPLEMENTARY USE OF AMINO-ACID EPIMERIZATION AND RADIOCARBON ANALYSIS FOR DATING OF MIXED-AGE FOSSIL ASSEMBLAGES
}

\author{
GLENN A GOODFRIEND \\ Isotope Department, Weizmann Institute of Science \\ 76100 Rehovot, Israel
}

\begin{abstract}
Several approaches to dealing with the problem of mixed-age fossil assemblages are presented. These involve the use of amino-acid epimerization analysis (D-alloisoleucine/Lisoleucine ratio, or $\mathrm{A} / \mathrm{I}$ ) and are illustrated by deposits of land snail shells. This method requires only very small samples, so shells can be analyzed individually. Mixed-age deposits are indicated when variation in A/I among individual shells within the deposit exceeds the analytical error. Methods are presented for 1) estimating the true time of deposition of slightlymixed-age assemblages based on bulk ${ }^{14} \mathrm{C}$ dates and epimer analyses, 2) selection (for ${ }^{14} \mathrm{C}$ analysis) of a set of individual shells that are uniform in age and represent the true time of deposition, and 3) estimating ages of individual shells within a mixed-age deposit based on their A/I ratios.
\end{abstract}

\section{INTRODUCTION}

In dating deposits, one may be interested in determining the time of deposition of the sediments or the age of the materials contained within the sediments. When sediments contain either redeposited or intruded materials, results for both types of dating by analysis of bulk samples will be erroneous. Analyses of single specimens of these materials may also yield ages that differ from the time of deposition. Such mixed-age assemblages are known to occur in a variety of types of deposits, eg, colluvium (Goodfriend, 1987a), fluvial deposits (Goodfriend, 1987a), cave sediments and karstic dissolution hole fills (Goodfriend \& Mitterer, 1987, 1988), peat (Jackson, Whitehead \& Davis, 1985), packrat middens (Van Devender et al, 1985), and marine sediments (Broecker et al, 1988).

The problem of mixed-age deposits probably often goes undetected by standard dating methods - bulk analyses may give results which are perfectly consistent stratigraphically, with the average age indeed increasing with depth. Analyses of single specimens may not be sufficiently numerous to detect the mixtures. Accelerator mass spectrometric (AMS) analysis of ${ }^{14} \mathrm{C}$ has made possible the analysis of very small specimens and, thus, has greatly expanded the range of specimens for which individual analyses are possible. However, full documentation of the age ranges of materials at each level of a deposit generally involves many analyses and requires considerable investment of time and money.

Here I describe an alternative approach to detecting and unraveling the chronology of mixed-age assemblages by means of amino-acid epimerization and ${ }^{14} \mathrm{C}$ measurements. Analysis of amino-acid epimer ratios (Dalloisoleucine/L-isoleucine, or $\mathrm{A} / \mathrm{I}$ ) is relatively easy and inexpensive to perform, thus permitting study of numerous individuals, and requires only small sample sizes (micrograms or even nannograms of amino acids). This approach is illustrated by examples of deposits containing land-snail shells. Amino-acid epimer ratios of land snails are strongly correlated with age 
$(r=0.95)$ in deposits such as fluvial sediments, archaeological fills, and rodent burrow middens, where the shells are not exposed to high temperatures on the surface for a long time before burial (Goodfriend, 1987b). A weaker relationship is found in colluvial deposits, apparently due to enhanced but variable epimerization induced by exposure to high temperatures on the surface before burial.

\section{METHODS}

Land-snail shells were cleaned of secondary carbonate deposits according to the methods of Goodfriend (1987a). Amino-acid epimer analyses were carried out by high-pressure liquid chromatography (HPLC) of hydrolysates of ca $75 \mathrm{mg}$ of shell material (Goodfriend, 1987a). Precision of the analyses (reproducibility of measurements of replicate preparations of a ground land snail shell standard) averages \pm 0.015 for Negev land snails and \pm 0.01 for the Jamaican land snails. The latter analyses were carried out by R M Mitterer (Geosciences Program, University of Texas at Dallas).

The ${ }^{14} \mathrm{C}$ dates reported here were corrected for fractionation (Goodfriend, $1987 \mathrm{c}$ ) and age anomaly due to ingestion of old carbonates by the snails (Goodfriend, 1987c). The uncertainty of the age anomaly correction is included in the reported precision of the ${ }^{14} \mathrm{C}$ determinations.

\section{DETERMINATION OF AGE UNIFORMITY OF ASSEMBLAGES}

Individual shells that are buried together at the same time within a stratum should undergo epimerization at the same rate and therefore show uniform $\mathrm{A} / \mathrm{I}$ values. Thus, deposits that have uniform $\mathrm{A} / \mathrm{I}$ values among shells (ie, the variability of $A / I$ is within the analytical error) should be of uniform age. Such uniformity is indeed found in land snail middens in rodent burrows (Goodfriend, 1987a), which accumulate within a geologic moment of time (months or years). Uniform A/I values, indicative of

\section{TABLE 1}

Measurements of alloisoleucine/isoleucine ratios of shells of the land snail Trochoidea seetzeni from the deposits in the Negev Desert, Israel. Locations are given in local grid coordinates $(\mathrm{E}-\mathrm{W}, \mathrm{N}-\mathrm{S})$

\begin{tabular}{|c|c|c|c|c|c|c|c|}
\hline \multirow{3}{*}{$\begin{array}{c}\begin{array}{c}\text { Site } \\
\text { no. }\end{array} \\
301\end{array}$} & \multirow{3}{*}{$\begin{array}{l}\text { Location } \\
149,051\end{array}$} & \multirow{3}{*}{$\begin{array}{c}\begin{array}{l}\text { Type of } \\
\text { deposit }\end{array} \\
\text { Iadi terrace }\end{array}$} & \multicolumn{5}{|c|}{ Alloisoleucine/isoleucine } \\
\hline & & & \multicolumn{4}{|c|}{ Individual shell measurements } & \multirow{2}{*}{$\frac{\bar{X} \pm \text { Std Dev }}{0.140 \pm 0.010}$} \\
\hline & & & $\begin{array}{l}0.131 \\
0.141\end{array}$ & $\begin{array}{c}0.137 \\
0.159\end{array}$ & 0.137 & 0.138 & \\
\hline A4570 & 162,076 & Archaeological & $\begin{array}{l}0.109 \\
0.134\end{array}$ & $\begin{array}{c}0.112 \\
0.144\end{array}$ & 0.125 & 0.131 & $0.126 \pm 0.013$ \\
\hline 246 & 166,073 & Wadi terrace & $\begin{array}{l}0.225 \\
0.265\end{array}$ & $\begin{array}{l}0.228 \\
0.276\end{array}$ & $\begin{array}{c}0.231 \\
0.279\end{array}$ & 0.252 & $0.251 \pm 0.023$ \\
\hline 460 & 166,073 & Wadi terrace & $\begin{array}{l}0.071 \\
0.076 \\
0.124\end{array}$ & $\begin{array}{l}0.072 \\
0.086 \\
0.127\end{array}$ & $\begin{array}{l}0.073, \\
0.094, \\
0.130,\end{array}$ & $\begin{array}{l}0.076 \\
0.118 \\
0.259\end{array}$ & $0.109 \pm 0.053$ \\
\hline
\end{tabular}


uniform ages, occur in some fluvial deposits (eg, Site 301, Table 1) and in some archaeological deposits (eg, Site A4570, Table 1). Variability of A/I values among shells that exceeds the analytical error points to the existence of a mixed-age assemblage. Normally we would expect that the uniform age shells in a deposit were all modern at the time of deposition, so that the age of the shells indicates the time of deposition of the sediments. However, it is conceivable that under some circumstances, fossils could be redeposited without incorporation of any new individuals (ie, material that is modern at the time of redeposition).

Mixed-age assemblages can come about by two processes: redeposition of shells from an older deposit or intrusion of younger shells into the sediments (through cracks, burrows, human disturbance, etc). These processes may usually be distinguished by the sedimentology of the deposits. Several approaches to dealing with the dating problems of such mixed-age assemblages will now be considered.

\section{DATING THE TIME OF SEDIMENTATION IN SLIGHTLY MIXED-AGE DEPOSITS}

When variation of $\mathrm{A} / \mathrm{I}$ values among shells within a deposit exceeds the analytical error, an assemblage of mixed age is indicated (eg, the wadi terrace deposit at Site 246 , Table 1). A bulk ${ }^{14} \mathrm{C}$ analysis of such material will give an age that is older than the sedimentation event if redeposited shells are responsible for the age mixture or younger if the shells are intruded. A correction for this bias in the bulk ${ }^{14} \mathrm{C}$ age can be made by analysis of the $\mathrm{A} / \mathrm{I}$ measurements of the individual shells. The bias is determined by the difference between the mean A/I value of the bulk sample (based on multiple analysis of an aliquot of the ground bulk sample or on the mean of individual shell $\mathrm{A} / \mathrm{I}$ measurements) and the $\mathrm{A} / \mathrm{I}$ value representing the correct age of deposition. The latter is chosen according to whether the age mixture is judged to have come about by redeposition of older material or intrusion of younger material. The age bias of the bulk sample is converted to a per cent and this correction is made for the ${ }^{14} \mathrm{C}$ age.

As an example of this approach, I will consider the dating of a wadi terrace in the Negev Desert (Site 246). The land snails in this deposit show a variability in $\mathrm{A} / \mathrm{I}$ (Std Dev $=0.023$ ) which exceeds the analytical error, and which, based on the stratigraphy, must have come about by redeposition of some slightly older shells (intrusion is very unlikely). The group of shells which shows the lowest $\mathrm{A} / \mathrm{I}$ values, the standard deviation of which does not exceed the analytical error, consists of the four shells with $\mathrm{A} / \mathrm{I}$ from $0.225-0.252(\overline{\mathrm{X}} \pm$ Std Dev: $0.234 \pm 0.012)$. These are thus considered the youngest uniform-age component and the two shells with higher $A / I$ values are interpreted as redeposited older material. The mean of these four shells is $93 \%$ of the overall mean $(0.251)$ and since $\mathrm{A} / \mathrm{I}$ is approximately linear with time in this range of values, the ${ }^{14} \mathrm{C}$ age of the time of deposition represented by these four shells is taken to be $93 \%$ of the measured ${ }^{14} \mathrm{C}$ age of the bulk samples $(7100 \pm 300 \mathrm{BP})$, which is $6600 \mathrm{BP}$. For higher A/I ratios, A/I departs from linearity with respect to time and a transformation of $\mathrm{A} / \mathrm{I}$ values to a linear function (Mitterer, 1975) is required to calculate the percent correction. 
A disadvantage of this approach to correcting ${ }^{14} \mathrm{C}$ ages is that the analytical uncertainty of the correction factor itself, based on the A/I measurements, adds an additional uncertainty to the final calculated age. Furthermore, this correction method is useful only when a small age variation exists within the bulk sample. As the age variability within samples increases, the bulk ${ }^{14} \mathrm{C}$ ages depart from the mean ${ }^{14} \mathrm{C}$ age of the individual shells - the bulk ages become biased toward the age of the younger shells in the deposit. This is the result of the exponential decay of ${ }^{14} \mathrm{C}$ with time. For this reason, a different approach to dating of deposits containing fossils of a wide range of ages is required.

\section{DATING TIME OF SEDIMENTATION BY ${ }^{14} \mathrm{C}$ ANALYSIS OF INDIVIDUALLY} SELECTED SHELLS

${ }^{14} \mathrm{C}$ analysis of a set of shells with uniform $\mathrm{A} / \mathrm{I}$ values representing the age of deposition of the sediments selected out of a mixed-age assemblage gives a direct date for the time of sedimentation. An example of this approach is provided by the dating of a wadi terrace in the Negev (Site 460, Table 1). This deposit contains a mixed-age assemblage of shells, as indicated by the large variation in A/I among the 12 shells analyzed (Std Dev = $0.053)$. Of these 12 , the 7 with the lowest $\mathrm{A} / \mathrm{I}$ ratios $(0.071-0.094)$ comprise a uniform group (Std Dev $=0.009$ ) and should represent those shells that were modern at the time of deposition. The shell with $\mathrm{A} / \mathrm{I}=0.259$ clearly represents a specimen redeposited from the older terrace above (in which Site 246 is situated). Conventional ${ }^{14} \mathrm{C}$ analysis of a combined sample of the seven shells yielded an age of $1310 \pm 250 \mathrm{BP} .{ }^{14} \mathrm{C}$ analysis of a bulk, unselected sample of shells would clearly have led to an erroneously old age for the time of deposition of the wadi sediments.

\section{DATING OF INDIVIDUAL SHELLS WITHIN A MIXED-AGE ASSEMBLAGE}

Mixed-age assemblages present a particular problem for analysis of faunal chronologies, since the age of an individual specimen can be determined only by analysis of the individual itself. Full analyses of species chronologies may require many dozens to hundreds of analyses and, if carried out by AMS measurement of ${ }^{14} \mathrm{C}$, would be prohibitively expensive. As an alternative, relative chronologies can be worked out by amino-acid epimer analyses, for which hundreds of analyses are feasible, and these can be converted to estimated absolute chronologies by in-situ calibration of epimerization rates by ${ }^{14} \mathrm{C}$ measurement of selected samples.

This approach is illustrated by the study of the chronologies of land snail species in several mixed-age deposits from a site on the north coast of Jamaica (Goodfriend \& Mitterer, 1988). Because of the small size of most shells, only one sample was of sufficient size for conventional ${ }^{14} \mathrm{C}$ dating. A calibration of the ${ }^{14} \mathrm{C}$ time scale for this site was developed using this calibration date $(30,400 \pm 2580 \mathrm{BP}$ for a sample of shells with $\mathrm{A} / \mathrm{I}=0.51 \pm 0.02$ $(\overline{\mathrm{X}} \pm$ Std Error) $)$ and an assumed Pleistocene-Holocene difference in epimerization rates based on calibration dates from another cave site in Jamaica (see Goodfriend \& Mitterer (1988) for details). Based on these data and assumed first-order kinetics, the $\mathrm{A} / \mathrm{I}$ value expected for $10,000 \mathrm{BP}$ 


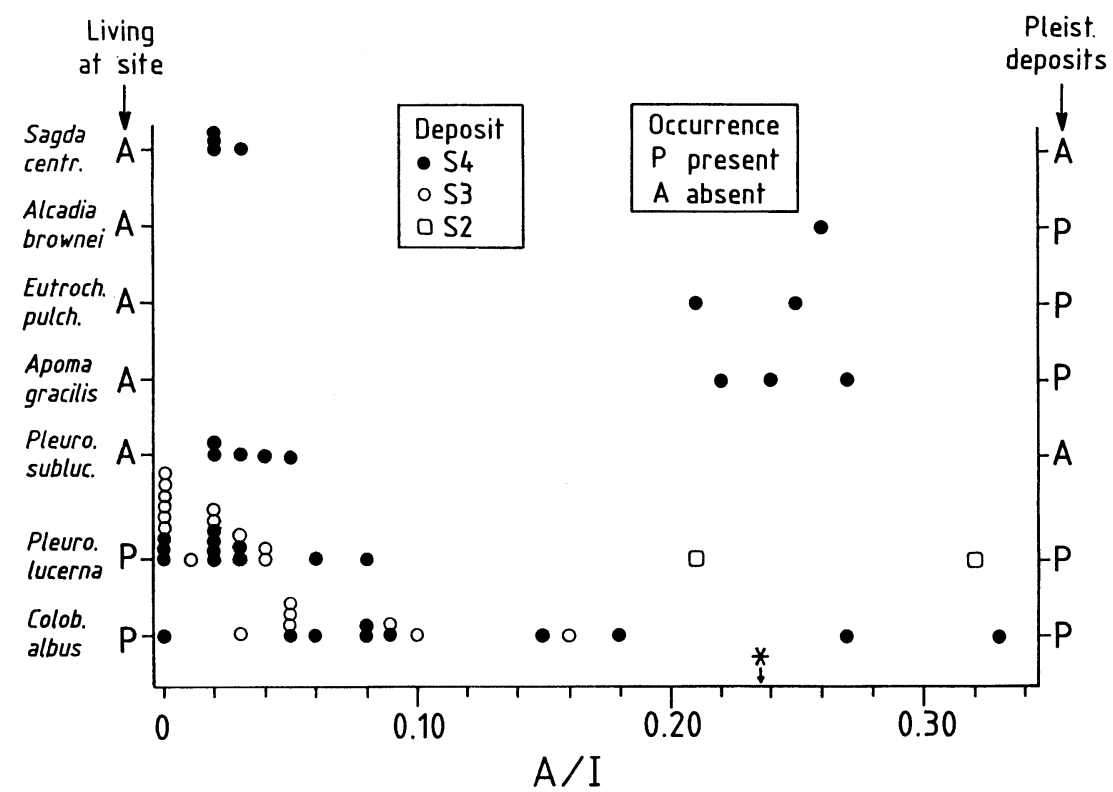

Fig 1. The chronology of some land snail species in some deposits at Green Grotto, Jamaica, based on alloisoleucine/isoleucine (A/I) analyses of individual shells. Also indicated is the presence or absence of each species at the site at present and in late Pleistocene deposits at the site. The estimated A/I value at the Pleistocene-Holocene boundary is given by the asterisk $\left({ }^{*}\right)$ (from Goodfriend \& Mitterer, 1988).

(the Pleistocene-Holocene transition) was estimated to be ca 0.24 . With only an approximate calibration such as this, nothing precise can be said about the chronology of species in the deposits. However, several interesting and clear patterns do emerge from the analysis of $\mathrm{A} / \mathrm{I}$ ratios. Several of the deposits contain assemblages of very mixed age (eg, deposits $\mathrm{S} 3$ and S4, Fig 1). Of 5 species that occur in the deposits but which are presently extinct at the site, 3 apparently disappeared some time around the Pleistocene-Holocene transition (Alcadia brownei, Eutrochatella pulchella and Apoma gracilis, Fig 1), whereas 2 species first appeared at the site only in late Holocene time (Sagda centralis and Pleurodonte sublucerna). Other species, such as Colobostylus albus, show continuous occupation of the site and still live there at present.

\section{POTENTIAL APPLICABILITY OF AMINO-ACID EPIMERIZATION TO} DATING OF MIXED-AGE DEPOSITS

Each of the approaches to dealing with mixed-age deposits presented here depends upon a strong correlation of amino-acid epimer ratios with age within a site. In fact there are few studies in which the age-predictive ability of amino-acid epimer (or enantiomer) ratios has been evaluated quantitatively. As discussed above, Holocene land snails from the Negev yield good 
results, except in colluvial deposits. This presumably is also true for other well-preserved samples of land snails. Epimerization and racemization in marine mollusks have been extensively studied and usually yield stratigraphically consistent results (eg, Mitterer, 1975; Miller et al, 1983) and rates that correlate geographically with temperature (eg, Miller \& Mangerud, 1985; Wehmiller, 1982). However, occasional inconsistencies have occurred in inter-site comparisons (eg, Wehmiller, 1982). Bone has certainly proved problematic and often shows quite variable rates of racemization among sites (eg, Lajoie, Peterson \& Gerow, 1980; Bada et al, 1984); within-site variation in racemization rates appears to be more directly related to age (eg, Bada \& Helfman, 1975). However, further study is required before the approaches to dating of mixed-age deposits discussed here can be applied to analysis of bones.

The minimum variation in age that can be detected within a deposit is limited by the precision of the amino-acid epimer analyses. Multiple analyses of single shells by HPLC can give A/I measurements with a precision (standard error) in the range of ca $2-5 \%$; age variation exceeding this amount can therefore be detected. Analysis by gas chromatography, though involving more work in sample preparation, can probably give results with better precision, thus reducing the limit of detection of age variation.

\section{ACKNOWLEDGMENTS}

The author is indebted to $\mathrm{R} M$ Mitterer for measurements of $\mathrm{A} / \mathrm{I}$ ratios of the Jamaican land snails, to I Carmi for providing ${ }^{14} \mathrm{C}$ dates, and to $\mathrm{G} \mathrm{H}$ Miller for helpful comments on the manuscript.

\section{REFERENCES}

Bada, J L, Gillespie, R, Gowlett, J A J and Hedges, J J, 1984, Accelerator mass spectrometry radiocarbon ages of amino acid extracts from California palaeoindian skeletons: Nature, $\mathrm{v}$ 312 , p 442-444.

Bada, J L and Helfman, P M, 1975, Amino acid racemization dating of fossil bones: World Archaeol, v 7, p 160-173.

Broecker, W S, Andrée, M, Klas, M, Bonani, G, Wölfli, W and Oeschger, H, 1988, New evidence from the South China Sea for an abrupt termination of the last glacial period: Nature, v 333, p 156-158.

Goodfriend, G A, 1987a, Chronostratigraphic studies of sediments in the Negev Desert, using amino acid epimerization analysis of land snail shells: Quaternary Research, v 28, p 374 392.

1987b, Evaluation of amino-acid racemization/epimerization dating using radiocarbon-dated fossil land snails: Geology, v 15, p 698-700.

$1987 \mathrm{c}$, Radiocarbon age anomalies in shell carbonate of land snails from semi-arid areas: Radiocarbon, v 29, no. 2, p 159-167.

Goodfriend, G A and Mitterer, R M, 1987, Age of the ceboid femur from Coco Ree, Jamaica: Jour Vertebrate Paleont, v 7, p 344-345.

1988, Late Quaternary land snails from the north coast of Jamaica: local extinctions and climatic change: Palaeogeog, Palaeoclimat, Palaeoecol, v 63, p 293-311.

Jackson, S T, Whitehead, D R and Davis, O K, 1986, Accelerator radiocarbon date indicates mid-Holocene age for hickory nut from Indiana late-glacial sediments: Quaternary Research, v 25, p 257-258.

Lajoie, K R, Peterson, E and Gerow, B A, 1980, Amino acid bone dating: a feasibility study, south San Francisco Bay region, California, in Hare, P E, Hoering, T C and King, K, Jr, eds, Biogeochemistry of amino acids: New York, John Wiley \& Sons, p 477-489. 
Miller, G H and Mangerud, J, 1985, Aminostratigraphy of European marine interglacial deposits: Quaternary Sci Rev, v 4, p 215-278.

Miller, G H, Sejrup, H P, Mangerud, J and Andersen, B G, 1983, Amino acid ratios in Quaternary molluscs and foraminifera from western Norway: correlation, geochronology and paleotemperature estimates: Boreas, v 12, p 107-124.

Mitterer, R M, 1975, Ages and diagenetic temperatures of Pleistocene deposits of Florida based on isoleucine epimerization in Mercenaria: Earth \& Planetary Sci Letters, v 28, p 275-282.

van Devender, T R, Martin, P S, Thompson, R S, Cole, K L, Jull, A J T, Long, A, Toolin, $\mathrm{L} J$ and Donahue, D J, 1985, Fossil packrat middens and the tandem accelerator mass spectrometer: Nature, v 317, p 610-613.

Wehmiller, J T, 1982, A review of amino acid racemization studies in Quaternary mollusks: stratigraphic and chronologic applications in coastal and interglacial sites, Pacific and Atlantic coasts, United States, United Kingdom, Baffin Island, and tropical islands: Quaternary Sci Rev, v 1, p 83-120. 